\title{
Determination of Engineering Properties of some Selected Agricultural Crops
}

\author{
Nishanth M. Stanly, Arun Kumar, Ratnakiran D. Wankhade* and Annu Rani \\ Department of Farm Machinery and Power Engineering, College of Technology, \\ G.B.P.U.A \& T., Pantnagar, Uttarakhand, India \\ *Corresponding author
}

\section{A B S T R A C T}

\begin{tabular}{|l|}
\hline K e y w o r d s \\
Mechanization, \\
Engineering \\
Prosperities, \\
Threshing
\end{tabular}

The agriculture sector is rapidly progressing towards the mechanization. Taking in to consideration the need of doubling the farmer's income as well as reduction in the human drudgery the demand for agriculture mechanization is increasing day by day. Threshing is of the most laborious agriculture operation which required lots of human as well as animal energy. Still there are lots of agriculture crops which are threshed manually or with animal power. The engineering properties of the crops are very important when works on the machination of threshing. Hence, keeping in view the above points the present study was carried out for determining the engineering properties of Soybean, Black Gram and Rice likes grin size, spericity, moisture content...etc. It was clear from the study that the engineering properties vary from crop to crop. The grin size was observed maximum in case of soyabean while the value of some other properties was less than other crops. The maximum angle of repose was found in case of paddy. The details comparison of engineering properties is done in this paper.

\section{Introduction}

India is considered as the world's largest producer of pulse crops in the world. The pulses production in India has increased from 14.3 to 14.7 MT between the years 2007 to 2010. Production seasons in India are kharif (autumn) and rabi (spring). However, two thirds of India's production is during the rabi season which is between October and March. The crops that grow in the rabi period are pigeon peas, cowpea, mung beans and moth beans. It may also be noted that pulses are an important source of protein in the Indian diet especially for vegetarians. But the per capita availability of pulse declined from 61 to 32 g/day.

It is also estimated that total requirement of projected population of 1.55 billion will be 25.39 MT in 2024-2025. So the twelfth plan emphasizes the ensuring of increase in pulse production. The state of Madhya Pradesh is the largest pulse producer accounting for 
about $26 \%$ of total production. Other states with significant productions are Uttar Pradesh (18 \%), Maharashtra (14\%), Rajasthan (14 $\%)$, Karnataka (5\%), Andhra Pradesh (10\%), and Bihar (5\%). Chick pea, cowpea, pigeon pea, mung beans, urad beans, lentils, and field peas are considered as the India's main crops.

The soybean (Glycine max) is a species of legume native to East Asia, widely grown for its edible bean which has numerous uses. The plant is classed as an oilseed rather than a pulse by the UN Food and Agricultural Organization (FAO). Fat-free (defatted) soybean meal is a significant and cheap source of protein for animal feeds and many prepackaged meals; soy vegetable oil is another product of processing the soybean crop. For example, soybean products such as textured vegetable protein (TVP) are ingredients in many meat and dairy analogues. Soybeans produce significantly more protein per acre than most other uses of land. Traditional non fermented food uses of soybeans include soy milk, and from the latter tofu and tofu skin. The beans contain significant amounts of phytic acid, alphalinolenic acid and is flavones. The oil is used in many industrial applications. The main producers of soy are the United States (35\%), Brazil (27\%), Argentina (19\%), China (6\%) and India (4\%) (FAO).

Black gram originated in India, where it has been in cultivation from ancient times and is one of the most highly prized pulses of India. 1.4 MT urad bean is cultivated from an area of 3.1Mha. Even though black gram production area in India increased from 2916 to 3011.3 thousand tonnes, the yield reduced from 483 to $431 \mathrm{~kg} / \mathrm{ha}$. Andhra Pradesh, Maharashtra and Uttar Pradesh are the three major pulse producing states in India.

Rice is a major cereal crop in India which is one of the most important food crops of India in term of area, production and consumer preference. India is the second largest producer and consumer of rice in the world. Rice production in India crossed the mark of 100 million tonnes in 2011-12 accounting for $22.81 \%$ of global production (Agriwatch, 2013). Paddy, grown under diverse agro climatic conditions, occupies more than 40 million hectares area with average production of 90 MT. Inadequate post-harvest management is held responsible for the low production in 2009-2010. It is estimated that over 12 million threshers are now in use, the number can be raised to reduce the postharvest losses for life saving agriculture.

Threshing is the most important process among post-harvest processes. The process of loosening and separating grain from ear heads is called as threshing. Threshing may also be done by hand beating manually, animals treading or using different mechanical means available locally. Further, threshing by manual labor is slow, time consuming and a very laborious process. Indigenously, people used bullocks for threshing. With further advancements, the farmers started the use of dragging devices like rollers, wooden planks, disc harrow and finally Olpad thresher followed by power threshers. Keeping the above point in view study was conducted to study the engineering properties of the above mention crops.

\section{Materials and Methods}

Varieties of the selected crops and their physical properties

Pulse crops, soybean variety PS-1024 and black gram variety Pant Urad-31 were selected for the study as shown in Plate 1. In case of cereal crop, paddy variety selected was Pant Dhan-4. They were provided by the Crop Research Centre, Pantnagar. Physical properties of grain such as length, width, 
thickness, moisture content, sphericity, bulk density, true density, grain-pod ratio, coefficient of static friction and thousand grain weight were determined.

\section{Length, width and thickness}

For the determination of the sizes of the grains random samples consisting of thirty seeds of the crops were taken. The digital vernier caliper was used to determine their linear dimensions - length (L), width (B) and thickness (T).

\section{Grain size}

For estimating the size of grains, thirty grains of each variety were taken randomly. For deciding size of sieve for grains, diameters along three major axes (length, width and thickness) were measured and average diameter was determined (Mohsenin, 1970). It is useful for deciding sieve size and lower concave bar spacing. It is determined by the following equation:

$$
\text { Grain size }=(\mathrm{L} \times \mathrm{B} \times \mathrm{T})^{1 / 3}
$$

Where,

$\mathrm{L}=$ Length, $\mathrm{mm}$

$\mathrm{B}=$ Width, $\mathrm{mm}$

$\mathrm{T}=$ Thickness, $\mathrm{mm}$

\section{Sphericity}

Thirty grains from each variety were taken randomly to estimate the sphericity of grains. Further, to decide the shape of sieve for each crop, diameters along three major axis (length, width and thickness) were determined (Mohsenin, 1970). Elongated shaped sieve should be used for the crops with lesser shpericity whereas the shape of the sieves becomes round as the sphericity increases. Sphericity was determined by the following formula:

$$
\text { Sphericity }=\frac{(\mathrm{L} \times \mathrm{B} \times \mathrm{T})^{1 / 3}}{\mathrm{~L}}
$$

Where,

$\mathrm{L}=$ Length, $\mathrm{mm}$

$\mathrm{B}=$ Width, $\mathrm{mm}$

$\mathrm{T}=$ Thickness, $\mathrm{mm}$

\section{Moisture content}

Using the oven drying method moisture content was determined for three samples of grain from each variety. The known quantity of sample was placed in oven at $72^{\circ} \mathrm{C}$ for 24 hours (IS: 4333 II, 1968) and weight of dried samples was taken by electronic balance.

The average moisture content in percentage (dry basis) was reported. Threshing efficiency and resists load impact are affected by the moisture content; therefore it is an important property.

$$
\mathrm{M}_{\mathrm{c}}(\%)=\frac{(\mathrm{ww}-\mathrm{wd})}{\mathrm{wd}} \times 100
$$

Where,

$\mathrm{M}_{\mathrm{C}}=$ Moisture content. (db) \%

$\mathrm{W}_{\mathrm{W}}=$ Weight of material before oven drying, $\mathrm{g}$

$\mathrm{W}_{\mathrm{d}}=$ Weight of material after oven drying, $\mathrm{g}$

\section{Bulk density}

Using a container of known volume $500 \mathrm{cc}$, the volume of grains was determined. The container was filled with each variety of crop grain separately and its weight was taken on electronic balance having a least count of 0.01 g. Three replications were made. Average bulk density was determined (Mohsenin, 1970) using the following formula:

$$
\rho=\frac{W}{V}
$$


Where,

$\mathrm{P}=$ Bulk density $(\mathrm{g} / \mathrm{cc})$

$\mathrm{W}=$ Weight of sample, $\mathrm{g}$

$\mathrm{V}=$ Volume of sample, $\mathrm{cc}$

\section{True density}

True density of soybean grain was determined by Toluene-Displacement method (Mohsenin, 1970). A sample of $10 \mathrm{~g}$ was kept in $50 \mathrm{ml}$ pycnometer and toluene was added to fill up in the pycnometer and its weight was taken by using electronic balance. The weight of pycnometer filled with toluene only was also taken. Three replications should be taken for determining true density by the following formula.

$$
T=\frac{W}{\left(V_{2}-v_{1}\right)}
$$

Where, $\quad \mathrm{T}=$ True density, $\mathrm{g} / \mathrm{cc}$

$\mathrm{W}=$ Weight of grain, $\mathrm{g}$

$\mathrm{V}_{1}=$ Volume of toluene before filling the grain, cc

$\mathrm{V}_{2}=$ Volume of toluene after filling the grain, $\mathrm{cc}$

\section{Angle of repose}

The angle of repose is defined as the angle made by the heap of material while piled up with the horizontal. It was measured by an apparatus consisting of conical hopper mounted above a circular base plate of $33 \mathrm{~cm}$ diameter. A scale was attached to this set up for measuring the height of heap above the base.

A sample of grain was poured to from a conical heap above the base plate. The pouring was continued till the base plate was completely filled and grains just sliding outward. The height of the heap was measured by using the attached scale. The angle of repose was determined (Mohsenin,
1970) using the following relationship.

$$
\varnothing=\tan ^{-1}\left(\frac{2 \mathrm{~h}}{\mathrm{D}_{\mathrm{P}}}\right)
$$

Where,

$\varnothing=$ angle of repose, degree

$\mathrm{h}=$ height of the heap, $\mathrm{cm}$

$\mathrm{Dp}=$ diameter of the base plate, $\mathrm{cm}$

\section{Coefficient of static friction}

Coefficient of static friction was determined on metal sheet surface by the tilting surface method. It consists of a wooden plank of size $600 \times 275 \times 22.5 \mathrm{~mm}$ which is hinged to one end of lower plank of same size. A grain sample was taken and kept in the desiccators for 24 hours so that its moisture is uniformly distributed.

For determining friction between grain and M.S sheet surface, a metal sheet having $600 \times 275 \times 10 \mathrm{~mm}$ dimensions was placed over the upper plank of the apparatus. Five grains were placed over M.S sheet and upper plank was gradually raised by rope and pulley arrangement.

The height at which grains started sliding down was measured. The observations were repeated three times for each type of grain. The tangent of angle with the horizontal was calculated which gives angle of friction between grain and M.S sheet. It is useful to determine the angle at which chutes must be positioned in order to achieve consistent flow of material through the outlet chute.

\section{Grain-pod ratio}

The grain-pod ratio was determined by taking 30 pods of each variety and the weight of clean grains from each pod was noted. The ratio of the weight of clean grains to the pod weight gives the grain-pod ratio. Thus, if the 
amount of unthreshed crop is known, the weight of clean grains can be determined. An electronic balance with $0.01 \mathrm{~g}$ least count was used for weighing

\section{Thousand grain weight}

Three samples of each crop were taken and their weight determined by an electronic balance with a least count of $0.01 \mathrm{~g}$. Number of grains in each samples was counted and thousand grain weight of each sample (IS: 4333 II, 1968) was calculated by following relationship:

Thousand grain weight $=a / b^{\times} 10$

Where,

$\mathrm{a}=$ Weight of sample, $\mathrm{g}$

$\mathrm{b}=$ Number of grains in sample

\section{Results and Discussion}

The engineering properties of soybean, black gram and paddy crops viz., bulk density, true density, grain size, sphericity, thousand grain weight, coefficient of static friction, angle of repose, straw - grain ratio, grain pod ratio, moisture content were determined. The average values are represented in Table 1

The physical dimensions of the grains were taken to determine the grain size of different crops of soybean, black gram and paddy. Grain size or equivalent diameter of grains of soybean crop ranged between $4.01-6.31 \mathrm{~mm}$ with a standard deviation of 0.76 . For black gram crop, grain size ranged between 2.32$3.95 \mathrm{~mm}$ with standard deviation of 0.56 while for paddy it ranged between 3.32-3.47 $\mathrm{mm}$ with a standard deviation of 0.05 .

Sphericity of soybean, black gram and paddy was found in the range of 0.66-0.87, 074-0.87 and $0.35-0.37$, respectively. Sieve size was decided based on the sphericity of grains. The more the sphericity, the more round will be the sieve. Maximum grain pod ratio was found in soybean after black gram in which the average values obtained were 2.48 and 2.15 respectively.

Table.1 Engineering properties of different crops

\begin{tabular}{|c|c|c|c|c|}
\hline $\begin{array}{c}\text { Sl. } \\
\text { No. }\end{array}$ & Properties & Soybean & Black gram & Paddy \\
\hline $\mathbf{1}$ & Grain size (mm) & 6.31 & 3.58 & 3.42 \\
\hline $\mathbf{2}$ & Spericity & 0.87 & 0.83 & 0.39 \\
\hline $\mathbf{3}$ & Moisture content (\%) db & 13.2 & 12.8 & 14.75 \\
\hline $\mathbf{4}$ & Straw-grain ratio & 1.45 & 1.85 & 2.12 \\
\hline $\mathbf{5}$ & Grain-pod ratio & 2.48 & 2.15 & - \\
\hline $\mathbf{6}$ & Thousand grain weight (g) & 132.23 & 61.27 & 39.35 \\
\hline $\mathbf{7}$ & Bulk density (g/cc) & 0.86 & 0.93 & 0.69 \\
\hline $\mathbf{8}$ & True density (g/cc) & 1.31 & 1.61 & 1.14 \\
\hline $\mathbf{9}$ & Angle of repose (degree) & 27.61 & 25.42 & 29.93 \\
\hline $\mathbf{1 0}$ & Coefficient of static & 0.38 & 0.36 & 0.42 \\
\hline
\end{tabular}


Coefficient of static friction and angle of repose were found maximum in paddy as 0.45 and $29.5^{\circ}$, respectively which have greater role in deciding the inclination of the grain outlet for consistent flow. Bulk density and true density are the important properties for sizing grain hoppers and storage facilities.

Maximum bulk density and true density of black gram were found to be 0.93 and $1.61 \mathrm{~g} / \mathrm{cc}$, respectively. Thousand grain weight was found to be maximum in soybean (132.23 g) and least in paddy $(39.35 \mathrm{~g})$.

The moisture content of crops was a highly influential factor in overall performance of the machine which was found to be optimum at the time of threshing. The average moisture contents at the time of threshing of soybean, black gram and for paddy were 13.2, 12.8 and $14.7 \%$, respectively.
It is concluded from the results that all the crops have different physical as well as engineering properties. Hence, there is need to fix the sieve size, shape, angle of grain outlet chute, clearance between the horizontal and vertical rods of lower concave taking in to consideration all engineering properties of the crops for designing required thresher.

\section{References}

Indian Standard Codes. 1968. Method of analysis for food grains, moisture. IS: 4333 II,

Mohsenin, N.N. 1970. Physical properties of plant and animal materials. Vol.1. Gordon and Breach Science publishers, New York, U.S.A

TNAU Agritech Portal Seed Technology. 2013. www. TNAU Agritech Portal Seed Technology.Transaction of ASAE. 16(6): 1154-1157.

\section{How to cite this article:}

Nishanth M. Stanly, Arun Kumar, Ratnakiran D. Wankhade and Annu Rani. 2020. Determination of Engineering Properties of some Selected Agricultural Crops. Int.J.Curr.Microbiol.App.Sci. 9(03): 3002-3007. doi: https://doi.org/10.20546/ijcmas.2020.903.344 